\title{
Control of Black Vine Weevil larvae Otiorhynchus sulcatus (Fabricius) (Coleoptera:Curculionidae) in grow bags outdoors with nematodes
}

\author{
Theodora Lola-Luz ${ }^{*} \boldsymbol{\dagger}$, Martin Downes ${ }^{*}$ and Richard Dunne† \\ *Department of Biology, Institute of Bioengineering and Agroecology, National University of Ireland, Maynooth, Co. Kildare and $\dagger$ Teagasc \\ Kinsealy, Malahide Road, Dublin 17, Ireland
}

\begin{abstract}
Outdoor trials were carried out during 2001-02 on strawberries grown in commercial growing bags naturally infested with black vine weevil larvae (BVW) Otiorhynchus sulcatus in Co. Wexford, Ireland.

2 The two nematode isolates used in these trials were Heterorhabditis megidis (UK211) and Heterorhabditis downesi (K122), both laboratory cultured. Growing bags received nematodes either once (May 2001), twice (May and October 2001) or three times (May, October 2001 and May 2002). Ten days after each application date, nine blocks (of the total 27) were randomly selected, destructively assessed and discarded.

3 The single application (May 2001) resulted in a mortality of black vine weevil larvae, of $93.4 \%$ with $H$. megidis and $51.3 \%$ with $H$. downesi, compared with the control treatment at that date. Respective figures after the double application (May 2001 and October 2001) were 78.9 and 77.6\% and after the triple application (May 2001, October 2001 and May 2002) the figures were 93.7 and $88.1 \%$.

4 Results from these trials clearly indicate that entomopathogenic nematodes are good alternatives to chemical control of the black vine weevil on strawberries grown in growing bags in Ireland.
\end{abstract}

Keywords Biological control, entomopathogenic nematodes, Heterorhabditis downesi, Heterorhabditis megidis, Otiorhynchus sulcatus.

\section{Introduction}

The black vine weevil Otiorhynchus sulcatus (Fabricius) has become a serious pest throughout the world. Its importance has increased with the growing of ornamental plants in containers and, more recently, with the container growing of strawberries. It infests a wide range of horticultural crops, such as strawberries and blackcurrants where it causes serious damage (Penman \& Scott, 1976; Miller, 1979). The known host range of the black vine weevil includes 140 plant species (Warner \& Negley, 1976; Smith, 1932). Damage to the host is mainly caused by the larvae feeding on the roots (Smith, 1932; Moorhouse et al., 1992). This results in reduced vigour and, in cases where the infestation is heavy, plant death can also occur (Garth \&

Correspondence: Theodora Lola-Luz. Tel.: +1 628 5222; fax: +1 70838 45; e-mail: theodora.lolaluz@may.ie
Shanks, 1978). Although adult vine weevils feed on the foliage of the plant, they do not cause as much damage as the larvae, except that they may alter the decorative appearance of the plants (Schread, 1972; Bedding \& Miller, 1981; Georgis \& Poinar, 1984). The black vine weevil is a major pest of cyclamens in glasshouses (Smith, 1932), whereas Taxus sp. are frequently attacked in nurseries (Smith, 1927; Neiswander, 1953). Until the early 1970s, O. sulcatus larvae were controlled by incorporation in the soil of the persistent organochlorine aldrin. This treatment provided a good and lasting control of the weevils. However, in the early 1990s, the incorporation of aldrin in the soil was no longer permitted in the U.S.A. and Europe for environmental and toxicological reasons (Cross et al., 1995). The banning of organochlorine compounds and the lack of effective alternatives has contributed to increased damage and the importance of finding another control for black vine weevil. Control of the larvae has been attempted with other chemicals, such as a slow release granular 
formulation of chorpyrifos, but this has not achieved the same level of control as aldrin (Cross et al., 1995). More recently, imidacloprid has been used for the control of vine weevil larvae in non-food crops. During the last decade, there has been an increased interest in controlling insect pests by more environmentally friendly methods. Biological control offers an alternative, especially in crops such as strawberries, where the use of chemicals close to harvest is not permitted.

Entomopathogenic nematodes in the families Heterorhabditidae and Steinernematidae are currently being used as biological control agents against many pests, among which is the black vine weevil. These nematodes form nonfeeding dauer larvae, which are mutualistically associated with insect pathogenic bacteria in the genera Photorhabdus and Xenorhabdus, respectively. The nonfeeding dauer larvae of both genera migrate and locate insect hosts, which are entered through natural openings (mouth, spiracles or anus). Heterorhabditis sp. are also capable of direct penetration through the insect cuticle. The nematodes enter the insect haemocoel where they release their associated bacteria, which multiply and cause the host to die from septicaemia within approximately $48 \mathrm{~h}$. The nematodes feed on the bacteria and the breakdown products of the insect. They develop into adults and reproduce within the insect cadavers from which many thousands of new dauer larvae may emerge. Entomopathogenic nematodes have been successfully used to control black vine weevil larvae in potted plants and glasshouse crops (Bedding \& Miller, 1981; Simons, 1981; Georgis \& Poinar, 1984; Zimmermann \& Simons, 1986; Kakouli-Duarte et al., 1997; Wilson et al., 1999; Fitters et al., 2000). Some of the advantages of using entomopathogenic nematodes are that they are effective against a wide range of soil inhabiting pests, they are easy to apply, safe to vertebrates and have little or no impact on nontarget arthropods (Kaya \& Gaugler, 1993; Georgis et al., 1991).

The main objective of the present study was to evaluate the potential of the commercialized isolate (UK211) of Heterorhabditis megidis and an Irish isolate (K122) of Heterorhabditis downesi for the control of black vine weevil larvae, on strawberries grown in growing bags outdoors in Ireland. A further objective was to investigate the effect of combined spring and autumn applications.

\section{Materials and methods}

The nematodes used in this experiment were the U.K. isolate of $H$. megidis (UK211) and the Irish isolate H. downesi (K122). The trials were carried out in the Teagasc Soft Fruit Research Station in Clonroche, Ireland. For all trials, the nematodes were cultured in late-instar larvae of the greater wax moth Galleria mellonella (L.) (Lepidoptera: Pyralidae) (The Mealworm Co., U.K.) at $20^{\circ} \mathrm{C}$. The infective juveniles were recovered in White traps (White, 1927). The emerging infective juveniles were washed three times by sedimentation in tap water and then stored in shallow water in plastic food containers (Roundstone Catering, U.K.) at a concentration of 2000 nematodes per $/ \mathrm{mL}$. The nematodes were stored at $7{ }^{\circ} \mathrm{C}$ for 4 weeks or until used in the experiments. For each application date, the two nematode isolates were harvested at the same time and stored for the same period and under the same conditions.

Strawberry plants were grown in commercial growing bags $(40 \mathrm{~L})$ containing medium grade, peat based, compost (Bord na Mona, Ireland). Eleven holes were opened in each bag and one Elsanta plant was placed on each opening. The plants were cropped for their first year in a polythene tunnel. In their second cropping year, raised beds were constructed outdoors and covered with Mypex ${ }^{\circledR}$ (Polytunnels, U.K.), to suppress weed growth. The bags were then placed on top of the raised beds. The plants were therefore in their second cropping year and naturally infested with black vine weevil, when the experimentation with entomopathogenic nematodes began. To verify that vine weevil was present in the grow bags, a few of the bags were destructively assessed and the presence of vine weevil larvae was validated. All adults recovered in May 2001 and May 2002 were $O$. sulcatus. A complete randomized block experimental design was used. Each block contained a grow bag, replication of each of the three treatments: (i) H. downesi, (ii) H. megidis and (iii) control (water), and there were 27 blocks in total. The compost around each plant was inoculated with 25000 nematodes in $55 \mathrm{~mL}$ of water. The untreated control plants received only $55 \mathrm{~mL}$ of water.

Nematodes were applied on 17 May 2001, 2 October 2001 and 14 May 2002. Ten days after each nematode application, nine blocks were randomly chosen and the compost in each grow bag was thoroughly examined for larvae of $O$. sulcatus. Numbers of all alive and dead larvae were recorded, although the latter were not useful because of uncertainty about whether or not all were found. The assessed bags were then discarded.

Nematode quality was assessed by testing the nematode suspension in laboratory bioassay before and after application (same day). In brief, $1 \mathrm{~kg}$ of fine sand, containing $8 \%$ moisture, was used. One late-instar larva of G. mellonella was placed at the bottom of a plastic container $(40 \mathrm{~mm}$ height $\times 45 \mathrm{~mm}$ in diameter), which was then filled with moist sand. One $\mathrm{ml}$ of nematode suspension (100 nematodes $/ \mathrm{mL}$ ) was applied at the top of the container. Each bioassay with nematode suspension taken before and after nematode application was replicated 10 times in May 2001 and May 2002 and five times in Autumn 2001. The containers were left at room temperature for 7 days, after which the number of dead insects was recorded. All insects were dissected and the number of adult nematodes counted.

Meteorological data were obtained from a weather station located in the Research Station in Clonroche beside the trial plots (soil temperatures). Soil temperatures were recorded at 5, 20 and $30 \mathrm{~cm}$ daily. The one most likely corresponding to the conditions in the grow bag is the recording of temperature at $5 \mathrm{~cm}$. This is not an accurate recording and temperatures are likely to have fluctuated in the grow bags more than in the soil. The temperature recording at $5 \mathrm{~cm}$ was therefore regarded as an indication of the average temperature during the experiment. 
Statistical tests were performed using Minitab (Windows version 13.1, Minitab Inc., State College, PA). Counts from the randomized complete block design were compared overall using Friedman's nonparametric test. Friedman's test at was used post hoc to locate differences. Pairs of bioassay treatments, in fully randomized designs, were compared using the Mann-Whitney nonparametric test.

\section{Results}

The mean number of live insects of $O$. sulcatus recorded in these experiments is presented in Fig. 1. Except in May 2001, when some pupae and 4 adult weevils were found, on the other two assessment dates (October 2001 and May 2002) all insects were in their larval stage. Temperatures were characteristic for that particular time of year in Ireland (Table 1). Overall, in all three application dates, the two isolates $H$. megidis and $H$. downesi, reduced the number of live black vine weevil larvae and pupae relative to the control (Fig. 1). On all three assessment dates, 100\% of the larvae found in the control growing bags were alive. In the first application date (May 2001) there were significant differences among treatments in the number of live insects recovered (Friedman, d.f. $=2, P<0.001$ ). In addition to that there were significant differences between the two nematode species, H. megidis and $H$. downesi, which resulted in $93.4 \%$ mortality for the former and $51.3 \%$ for the latter (Fig. 1). The trend of reduced number of live black vine weevil larvae, recovered from growing bags that had received treatment with entomopathogenic nematodes was confirmed in the second (October 2001) application, when $H$. megidis induced $78.9 \%$ and $H$. downesi $77.6 \%$ mortality. Similar results were obtained in the third (May 2002) application date when H. megidis induced $93.7 \%$ and $H$. downesi $88.1 \%$ mortality. However, there were no differences detected between the two nematode species. In the infectivity bioassays that were done with the nematode suspension kept before and after application, it was found that there were no significant differences in the nematode infectivity between the two nematode suspensions in H. megidis (Mann-Whitney, $P=0.096$ ). However in the $H$. downesi bioassay there were significant differences between the two suspensions (Mann-Whitney, $P=0.008$ ), recovering more nematodes from the late instar larvae $G$. mellonela infected with suspension kept before the nematode application. The bioassay with insect parasitic nematode suspension kept before and after application in October 2001 and May 2002, showed no significant differences in infectivity.

\section{Discussion}

In all three application dates (May 2001, October 2001 and May 2002) the number of live black vine weevil larvae recovered from growing bags that had received treatment with entomopathogenic nematodes was much lower when compared with the control growing bags. Similar results have been reported in other studies (Simons, 1981; Georgis \& Poinar, 1984; Burlando et al., 1993; KakouliDuarte et al., 1997; Fitters et al., 2000). The results indicated that repeated applications of entomopathogenic nematodes (October 2001 and May 2002) can help to keep the weevil population low. This is in agreement with another study where strawberries that were grown in pots placed on benches outdoors had fewer live larvae in the pots receiving two and three nematode applications compared with one application (Lola-Luz, unpublished data).

A number of studies have indicated that 10 000-20000 nematodes/plant are effective in controlling larvae of the black vine weevil on potted strawberries when dispersed thoroughly in the soil medium (Bedding \& Miller, 1981; Georgis \& Poinar, 1984; Klinger, 1988; Kakouli-Duarte et al., 1997). However, for the purpose of the present study, an application rate of 25000 entomopathogenic

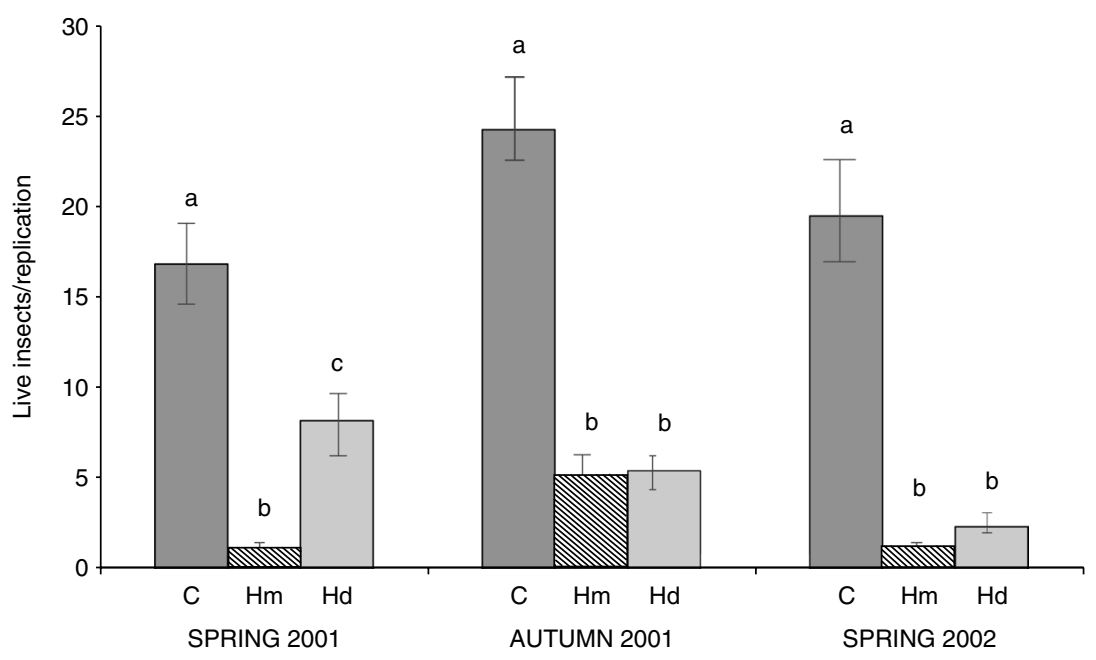

Figure 1 Mean \pm SEM number of live insects, after one, two and three applications of entomopathogenic nematodes. Different letters above bars indicate statistical differences (Friedman, d.f. $=2, P<0.01$ ). C, Controll Hm, Heterorhabditis megidis; Hd, Heterorhabditis downesi. 
Table 1 Average soil temperature $\left({ }^{\circ} \mathrm{C}\right)$ during the trials

\begin{tabular}{llll}
\hline Soil depth $(\mathrm{cm})$ & May 2001 & October 2001 & May 2002 \\
\hline 5 & 12.3 & 11.9 & 12.5 \\
20 & 12.4 & 13.0 & 12.3 \\
30 & 12.6 & 13.9 & 12.6 \\
\hline
\end{tabular}

nematodes/plant was used. This is the recommended rate for commercialized nematodes (Becker Underwood, Ames, Iowa; formerly Microbio).

The first application of entomopathogenic nematodes in May 2001 coincided with the presence of late larval and pupal stage of the BVW in the grow bags. It has been reported that these developmental stages of the black vine weevil are the most susceptible to infection by entomopathogenic nematodes (Kakouli, 1995; Kakouli-Duarte et al., 1997). This was further supported by the data in May 2001 where several pupae were found to be parasitized by both nematodes. Location of the host by entomopathogenic nematodes is a direct response to stimuli released by the host insect such as temperature gradients (Byers \& Poinar, 1982), carbon dioxide (Gaugler et al., 1980) and excretory products (Schmidt \& All, 1979). It is more likely that the amount of stimulants is greatly affected by the size of the insect. Subsequently, larger insects (in the spring) will be much easier to locate compared with smaller sized ones (in the autumn). In addition, a larger host will have more chances of encountering nematodes in the soil due to its body size (Kakouli, 1995) and nematodes could penetrate and infect such hosts more easily due to larger body openings. The two nematode species exhibited large differences only after a single application in May 2001 (Fig. 1). This difference was not reflected in the results after a second (October 2001) and a third (May 2002) application. From Fig. 1, it is clear that $H$. megidis performed better than the indigenous, Irish isolate $H$. downesi, by killing more larvae in all three application dates. The fact that $H$. downesi was isolated in Ireland and therefore better adapted to the local environment did not have a major effect in its ability to achieve better control than H. megidis. This is in contrast to another study, where $H$. downesi was used to control a population of the pine weevil (Hylobius abietis) on pine stumps. It was estimated that the highest level of parasitization was $60 \%$ with $H$. downesi, whereas the results obtained with $H$. megidis were not satisfactory (Dillon et al., 2002). In a study carried out under laboratory conditions, with the three nematode species Steinernema kraussei, Steinernema feltiae and H. megidis, S. kraussei was consistently the most virulent nematode at low temperatures $\left(6{ }^{\circ} \mathrm{C}\right)$. Heterorhabditis megidis invaded black vine weevil only when temperatures reached a minimum of $10^{\circ} \mathrm{C}$ (Long et al., 2000).

Less live black vine weevil larvae were recovered in May 2002 than October 2001. This difference between the two application dates indicates the possibility of nematodes recycling within the peat. In cases where a continuous number of larvae of $O$. sulcatus is provided, it is possible that a sufficient number of entomopathogenic nematodes is produced, which in turn would provide satisfactory control of black vine weevil (Kakouli, 1995). Other studies have also demonstrated the possibility of long persistence of nematodes in soil. Fleming (1968) reported that Steinernema glaseri persisted in the field for 14 years with populations of Popilla japonica of less than $54 \mathrm{grubs} / \mathrm{m}^{2}$. In another study, where nematode persistence was evaluated in the presence and absence of host, it was shown that in the trial plots where the host was present successful recycling of the nematodes was recorded (Kaya, 1990). Nematodes were recovered from the soil almost 1 year after the initial application. It is possible that other insects have served as hosts for the nematodes because no insects were added in the soil for the duration of the experiment (Kaya, 1990). Recycling of nematodes can be easily achieved in infested glasshouses where there is a constant supply of vine weevil larvae and temperatures are adequate to ensure nematode infection. However, things become more complicated with respect to crops grown outdoors, where low temperatures can be a limiting factor.

Temperature is a critical factor in the effectiveness of entomopathogenic nematodes. Indeed, one of the factors affecting the use of nematodes in Ireland are the low soil temperatures that occur when larvae and pupae are present in the soil. If the application of the nematodes is to succeed, it is very important that soil temperatures do not fall below $12{ }^{\circ} \mathrm{C}$ before and after application (Backhaus, 1994; van Tol, 1996; Fitters et al., 2000). During spring to early autumn, soil temperatures are adequate for nematode establishment. In these trials, the average temperature during October 2001 at $5 \mathrm{~cm}$ was almost half a degree lower than that in May 2001 and May 2002 (Table 1). However, it is very likely that, during the autumn application, temperatures fell to lower levels compared with spring time. A drop in temperature would have limited the infectivity of the nematodes, which are known to be temperature sensitive. This is also the only date at which the two isolates performed poorly (Fig. 1). In such conditions, although nematodes would lose their ability to cause infection, they would still be able to move in the soil (Hominick \& Reid, 1990). It is possible that they could still enter hosts but the symbiotic bacteria would not be able to multiply and therefore support nematode development. Backhaus (1994) reported that nematodes will infect black vine weevil larvae even at $8{ }^{\circ} \mathrm{C}$, but the associated bacteria Xenorhabdus sp. are unable to multiply below $12{ }^{\circ} \mathrm{C}$. Although the average temperature at $5 \mathrm{~cm}$ was $12.3^{\circ} \mathrm{C}$ in May $2001,11.9^{\circ} \mathrm{C}$ in October 2001 and $12.5^{\circ} \mathrm{C}$ in May 2002, it is likely that, during some days, the temperature did exceed $12{ }^{\circ} \mathrm{C}$, especially when exposed to direct sunlight. It would be expected that the temperature would be slightly higher in the grow bags compared with that of the soil. It has been reported that a temporary increase in the temperature above $12{ }^{\circ} \mathrm{C}$ for a few hours can influence positively the effectiveness of entomopathogenic nematodes (van Tol, 1993; Backhaus, 1994). Some work has also been carried out on conditioning nematodes to low temperatures by cold storage. In a recent study, Fitters et al. (2001) showed that storage of 
nematodes at $9{ }^{\circ} \mathrm{C}$ for $11-12$ weeks resulted in significantly higher mortality of BVW larvae (41\%) compared with nematodes stored at $20{ }^{\circ} \mathrm{C}$ for $2-3$ weeks $(12 \%)$. Promising results have also been provided by another study with the cold-active nematode Steinernema kraussei. Willmott et al. (2002) showed a high level of control of BVW larvae with $S$. kraussei compared with Steinernema carpocapsae, in a winter application with temperatures ranging from $-1.5{ }^{\circ} \mathrm{C}$ to $7.3{ }^{\circ} \mathrm{C}$. They indicate that, in a winter application in a semifield situation, S. kraussei caused a reduction of BVW larvae of up to $81 \%$, whereas $S$. carpocapsae did not exhibit any significant differences from control plants.

Effective control of the black vine weevil, especially on strawberry plants grown outdoors, is of great concern to growers. Ideally, entomopathogenic nematodes would be used to target the first instars of the weevil, thus preventing larvae from causing damage to the roots of the plants. However, because the last-instar larvae and pupae are the most susceptible stages to infection by nematodes, it may be better to target these stages. Although it would not be possible to eliminate totally the damage caused to the plants during the winter feeding, it might be possible to reduce the number of adults emerging in the next spring and therefore reduce the severity of the infestation in subsequent years. This present study has been demonstrated that nematodes in the family of Heterorhabditidae are able to successfully control larvae of the black vine weevil $O$. sulcatus in strawberries grown in grow bags outdoors in Ireland, both during spring and autumn. The best results were achieved when nematodes were applied in mid October and then again in spring. These two applications in the same cropping season had a direct effect on the number of surviving BVW larvae from autumn to spring in grow bags that had received treatment with nematodes (Fig. 1). Although this second application may not be financially attractive to many growers, it may help to reduce the number of adults that emerge at the beginning of June.

\section{Acknowledgements}

We thank Carmel O'Connor, Sue Cloney and Paul Fitters for their technical assistance. In addition, we thank Thomae Kakouli-Duarte for reviewing an earlier draft of the paper, and Christine Griffin and the two anonymous reviewers for their useful comments. This work was supported by Teagasc, through a Walsh fellowship.

\section{References}

Backhaus, G.F. (1994) Biological control of Otiorhynchus sulcatus F. by use of entomopathogenic nematodes of the genus Heterorhabditis. Acta Horticulturae, 364, 131-142.

Bedding, R.A. \& Miller, L.A. (1981) Use of a nematode, Heterorhabditis heliothidis, to control black vine weevil, Otiorhynchus sulcatus, in potted plants. Annals of Applied Biology, 99, 211-216.
Burlando, T., Kaya, H. \& Timper, P. (1993) Insect-parasitic nematodes are effective against black vine weevil. California Agriculture, 47, 16-18.

Byers, J.A. \& Poinar, G.O.J. (1982) Location of insect hosts by the nematode Neoplectana carpocapsae in response to temperature. Behaviour, 79, 1-10.

Cross, J.V., Buxton, J.H., Jacobson, R. \& Richardson, D.M. (1995) Chemical control of vine weevil larvae on containergrown hardy ornamental nursery stock 1986-89. Annals of Applied Biology, 127, 533-542.

Dillon, A., Downes, M. \& Griffin, C. (2002) Field assessment of impact of parasitic nematodes Heterorhabditidae and Steinernematidae on the immature stages of the large pine weevil. Offered Papers in Nematology: A One Day Conference at the Linnean Society of the London Association of Applied Biologists.

Fitters, P.F.L., Dunne, R. \& Griffin, C.T. (2000) Vine weevil control in Ireland with entomopathogenic nematodes: optimal time and frequency of application. Irish Journal of Agricultural and Food Research, 40, 199-213.

Fitters, P.F.L., Dunne, R. \& Griffin, C.T. (2001) Improved control of Otiorhynchus sulcatus at $9 \mathrm{c}$ by cold-stored Heterorhabditis megidis UK211. Biocontrol Science and Technology, 11, 483-492.

Fleming, W.E. (1968) Biological Control of the Japanese Beetle. Technical Bulletin 1383. United States Department of Agriculture, Washington, District of Columbia.

Garth, G.S. \& Shanks, C.H.J. (1978) Some factors affecting infestation of strawberry fields by the black vine weevil in western Washinghton. Journal of Economic Entomology, 71, 443-448.

Gaugler, R., Le Beck, L., Nakagaki, B. \& Boush, G.M. (1980) Orientation of the entomogenous nematode Neoplectana carpocapsae to carbon dioxide. Environmental Entomology, 9, 649-652.

Georgis, R. \& Poinar, G.J. (1984) Greenhouse control of the black vine weevil Otiorhynchus sulcatus (Coleoptera: Curcolionidae) by Heterorhabditid and Steinernematid nematodes. Environmental Entomology, 13, 1138-1140.

Georgis, R., Kaya, H. \& Gaugler, R. (1991) Effect of Steinernematid and Heterorhabditid nematodes (Rhabditida: Steinernematidae and Heterorhabditidae) on non target arthropods. Environmental Entomology, 20, 815-822.

Hominick, W.M. \& Reid, A.P. (1990) Perspectives in entomopathogenic nematology. Entomopathogenic Nematodes in Biological Control (ed. by R. Gaugler and H.K. Kaya), pp. 327-334. CRS Press, Boca Raton, Florida.

Kakouli, T. (1995) Biological control of the black vine weevil, Otiorhynchus sulcatus (F.) (Coleoptera: Curculionidae), with entomopathogenic nematodes (Nematoda: Rhabditida). PhD Thesis, University of Reading, Department of Agriculture, U.K.

Kakouli-Duarte, T., Labuschagne, L. \& Hague, N.G.M. (1997) Biological control of the black vine weevil, Otiorhynchus sulcatus (Coleoptera: Curculionidae) with entomopathogenic nematodes (Nematoda: Rhabditida). Annals of Applied Biology, 131, 11-27.

Kaya, H.K. (1990) Soil ecology. Entomopathogenic Nematodes in Biological Control (ed. by R. Gaugler and H.K. Kaya), pp. 93111. CRS Press, Boca Raton, Florida.

Kaya, H.K. \& Gaugler, R. (1993) Entomopathogenic nematodes. Annual Review of Entomology, 38, 181-206.

Klinger, J. (1988) Investigations on the parasitism of Otiorhynchus salicola and Otiorhynchus sulcatus (Coleoptera: Curculionidae) by Heterorhabditis sp. (Nematoda). Entomophaga, 33, 325-331.

Long, S.J., Richardson, P.N. \& Fenlon, J.S. (2000) Influence of temperature on infectivity of entomopathogenic nematodes (Steinernema and Heterorhabditis spp.) to larvae and pupae of 
the vine weevil Otiorhynchus sulcatus (Coleoptera: Curculionidae). Nematology, 2, 309-317.

Miller, L.A. (1979) Weevil pests of horticultural crops. Tasmanian Journal of Agriculture, 50, 52-53.

Moorhouse, E.R., Charnley, A.K. \& Gillespie, A.T. (1992) A review of the biology and control of Otiorhynchus sulcatus (Coleoptera: Curculionidae). Annals of Applied Biology, 121, 431-454.

Neiswander, R. (1953) Control of the black vine weevil. Journal of Economic Entomology, 46, 234-237.

Penman, D.R. \& Scott, R.R. (1976) Adult emergence and egg production of the black vine weevil in Canterbury, New Zealand. Journal of Experimental Agriculture, 4, 385-389.

Schmidt, J. \& All, J.N. (1979) Attraction of Neoplecta carpocapsae (Nematoda: Steinernematidae) to common excretory products of insects. Environmental Entomology, 8, $55-61$.

Schread, J.C. (1972) The black vine weevil. Connecticut Agricultural Experimental Station Circular no. 211. Connecticut Agricultural Experimental Station, New Haven, Connecticut.

Simons, W.R. (1981) Biological control of Otiorhynchus sulcatus with Heterorhabditid nematodes in the glasshouse. Netherlands Journal of Plant Pathology, 87, 149-158.

Smith, F. (1927) The black vine weevil (Prachyrhinus sulcatus Fabr.) as a pest in greenhouses and nurseries. Journal of Economic Entomology, 20, 127-131.

Smith, F. (1932) Biology and control of the black vine weevil. Technical Bulletin 325. United States Department of Agriculture, Washington, District of Columbia. van Tol, R.W.H.M. (1993) Efficacy of control of the black vine weevil Otiorhynchus sulcatus with strains of Heterorhabditis $\mathrm{sp}$, Steinernema sp. and the fungus Metarhizium anisopliae in nursery stock. Mededelingen van de Faculteit der Landbouwwetenschappen Rijksuniversiteit Gent, 58, 461-467.

van Tol, R.W.H.M. (1996) A strategy for control of the black vine weevil Otiorhynchus sulcatus in an integrated pest management programme in nursery stock. Second International Workshop on Vine Weevil Otiorynchus sulcatus Fabr (Coleoptera: Curculionidae), vol. 316, pp. 76-80. Blackwell, Berlin.

Warner, R.E. \& Negley, F.B. (1976) The genus Otiorhynchus in America north of Mexico (Coleoptera: Curculionidae). Proceedings of the Entomological Society of Washington, 78, 240-262

White, G.F. (1927) A method of obtaining infective nematode larvae from cultures. Science, 66, 302-303.

Willmott, D.M., Hart, A.J., Long, S.J., Edmondson, R.N. \& Richardson, P.N. (2002) Use of a cold-active entomopathogenic nematode Steinernema kraussei to control overwintering larvae of the black vine weevil Otiorhynchus sulcatus (Coleoptera: Curculionidae) in outdoor strawberry plants. Nematology, 4, 925-932.

Wilson, M., Nitzsche, P. \& Shearer, P.W. (1999) Entomopathogenic nematodes to control black vine weevil (Coleoptera: Curculionidae) on strawberry. Journal of Economic Entomology, 92, 651-657.

Zimmermann, G. \& Simons, W.R. (1986) Experiences with the biological control of the black vine weevil Otiorhynchus sulcatus. Proceedings of the Fourth International Conference of Invertebrate Pathology, pp. 529-533.

Accepted 10 January 2005 